\title{
Changes in the Polish Policy of Application of Criminal Law after 2016
}

\author{
Dr. habil. sc. pol. Jacek Zieliński \\ Siedlce University of Natural Sciences and Humanities, Poland \\ ja-nka6@wp.pl
}

\begin{abstract}
The recent changes in the Polish Criminal Law assume elimination of contradictory or unclear provisions, facilitation of jurisdiction as well as preventive measures through sharper penalties and, among others, implementation of new remedies of a non-custodial nature. Yet, they seem to prove less effective than anticipated, thus two key issues have been represented in the article: whether increasing the criminal liability affects the reduction of crime, therefore it is an element of prevention, and whether the judiciary should act quickly or fairly in criminal proceedings. The increase of liability appears to be irrelevant since measures of this kind ought to be preceded by developing a specific and promoted legal state policy. However, the fact remains that cases are still seized by courts with the long-term nature. Therefore, it is necessary to clarify whether it is due to inefficiency of the judicial system, or a defect of the legal system constituted by the Parliament.

Keywords: Criminal Law, penalty, prevention.

Judicial reform has been implemented in Poland for some considerable time now. This also includes gradual amendments to penal law. The action assumes elimination of contradictory or unclear provisions, facilitation of jurisdiction as well as preventive measures through sharper penalties and, among others, implementation of new remedies of a non-custodial nature. On such basis, several issues arise; this Paper will focus on two of them.

The first issue: Could sharper penalties be an element of prevention? Opinions are divided. Increased fines for speeding or drunk-driving are likely deterrents. Will they play the same role in fighting domestic violence, sexual abuse, murder or even theft? Not necessarily, because it involves dealing with different characteristics of offenders. On the basis of seeking solutions three questions arise.
\end{abstract}


Firstly, freedom of the court in applying maximum and minimum penalties. Mitigation has been quite frequently referred to so far, and suspended sentences have been pronounced, even in serious offences like rapes ( $40 \%$ with suspension). We would have to agree, however, with those who suggest that the problem concerns the application of law, not its content. Current reform efforts aim at administrative limitation of the leniency right and at giving suspended sentences through appeal at the request (or the order) of the Public Prosecutor - the Minister of Justice. The question arises: what is the essence of the reform - ensuring social justice or - under the slogan of social justice - imposing politically desirable reactions on courts. The problem may have, however, more complex consequences - within the meaning of the dismantling of judicial independence and objectivity of adjudication. Due to fear of their own existence, judges may begin to impose maximum penalties, thereby violating the principle of adequacy of punishment to guilt, and as a consequence of not applying suspension, affecting its constitutionally designated educational and preventive character. Contrary to appearances, this may encourage the patologization of particular social groups and vulnerability of courts to external influence.

The second problem related to the increase of penalties may actually be the question whether the state is prepared to the enforcement of punishment, and whether it has the sufficient infrastructure for detention, supervision of the convicted persons' behaviour outside a penitentiary and/or effective execution of sums decreed by judgments. The practice shows that this is problematic, therefore increasing the criminal liability means the depreciation of law which is deprived of real basis of feasibility.

The third problem to be aware of is that penitentiaries marginally perform their rehabilitation function, particularly towards those convicted for the most serious crimes - murders or rapes. There are no grounds to assume, with all responsibility, that signs of improvement observable in prison are of real and lasting nature. It may occur that deviants affect the behaviour of other inmates, who were put in prison merely because the court had been administratively prevented from applying a suspension of penalty against them. Serving the sentence and release does not solve the problem due to the effectiveness of supervision and the elimination of threats to society.

It was attempted to solve the problem through the amendment of the penal code (of 2015) [9] introducing new for the Polish penal pragmatics measures of non-custodial prevention: electronic control of residence, psychiatric therapy, addiction therapy as well as the possibility of applying an isolation precaution - a stay in a psychiatric institution as an additional penalty.

From the social point of view, the idea seems to be good as the primary responsibility of the state is to provide sense of security to all its citizens. The legislator did not amend, however, the basic law (they did not have such a majority) and the Ombudsman contested its decisions as unconstitutional at the Constitutional Court. In accordance with the Constitution nobody shall be subjected to medical experimentations without their consent. With the current medical knowledge, psychiatric therapy is 
experimentation, and what is more important, compliance with the law, the statutory regulation is doubtful when a person who has already served the sentence, is involuntarily placed in a psychiatric institution for an indefinite period. One cannot be punished twice for the same offence. Another question is the objective of such an action. In the situation when the legislator does not have the possibility of amending the Constitution, introduction of those institutions is a political marketing measure.

The second issue is an attempt to solve the problem of simultaneous occurrence of the basis for the application of extraordinary mitigation and tightening of punishment $[8,30 ; 10]$. The question arises whether mandatory implementation of one of the institutions is more important than optionality of the latter, or whether every time the decision ought to fall within the competence of the court. According to the doctrine, opinions are divided [6]. The fact remains that the court should first of all abide by general principles, and then particular ones, therefore it may impose lower or higher penalty. However, the logical contradiction may occur in the form of the simultaneous existence of conditions for leniency (cooperation and assistance) and tougher penalties (e.g. recidivism), when the court is allowed to impose the penalty at the upper limit or enlarge it by half.

Necessity for the resolution of at least two discrepancies is mentioned in literature:

1) an extraordinary mitigation of punishment in the case indicating the necessity of its extraordinary tightening [2];

2) an extraordinary tightening of punishment that has been extraordinarily mitigated [7, 374].

There are two approaches within that framework:

1) the declaration that the simultaneously existing conditions for leniency or tougher penalties cancel each other, therefore a punishment ought to be imposed according to regular principles [12];

2) the assumption that the acceptance of an extraordinary mitigation precludes an extraordinary tightening $[1,69]$. The Supreme Court has endorsed the latter approach [3, 339].

In accordance with the amendment that was to resolve the problem of simultaneous occurrence of conditions for an extraordinary mitigation or tightening of punishment, the judicature had been entitled to decide which prerequisites are considered essential when hearing cases. In other words, the court proceeds exclusively on the grounds of a selected basis, determining thereby the absence of illogical concurrence of adjudication standards [4, 453-454]. The solution seems to include judicial independence. The legislator has not determined the criteria for applying an extraordinary mitigation or tightening of punishment. Therefore the principle lege non distinguente nec nostrum est distinguere is in force.

There is still the unsolved problem of dealing with the occurrence of optionality of the basis for an extraordinary mitigation (or tightening) of punishment and its obligatory mitigation (or tightening). There is still a popular approach that although decision is at the discretion of the judiciary, we cannot talk about the reciprocal elimination of 
Jacek Zieliński. Changes in the Polish Policy of Application

of Criminal Law after 2016

an extraordinary mitigation or tightening, therefore - in consequence - about implementing the penalty within the framework of a regular legal threat as if there would not appear any circumstances for the extraordinary implementation of penalty [8,30]. The approach may be dangerous from the social point of view.

\section{Conclusion}

It seems that the legislator is not able or does not want to create a uniform and transparent system of penal law which would clearly regulate particular situations or eliminate inaccuracies noticed in the process of applying the legislation. The institutional changes related to the judicial reform seem to be sufficient to assume that it is about the direct or indirect interference of administration with justice and discretionary power to decide which judgment meets the criteria for justice, and which has been given without them. However, there is no unambiguous opinion regarding the identification of the boundary between the recognition of dignity and rights of the convicted person and the recognition of citizens' right to safety.

\section{Izmaiṇas Polijas krimināltiesību piemērošanas politikā pēc 2016. gada}

\section{Kopsavilkums}

Izmaiņas Polijas krimināllikumā paredz izvairīties no pretrunīgu vai neskaidru noteikumu formulējumiem, sekmēt tiesu iestāžu darbu un preventīvos pasākumus ar bargāku sodu palīdzību un pāri visam pielietojot jaunus tiesiskās aizsardzības līdzekḷus, kas nav tieši saistīti ar brīvības atņemšanu. Tomēr šīs izmaiņas škiet mazāk efektīvas, nekā sākotnēji iecerēts, tādēḷ rakstā tiek akcentēti divi galvenie jautājumi: pirmkārt, vai kriminālatbildības palielināšana ietekmē noziedzības samazināšanos un tāpēc tā ir preventīvs elements; otrkārt, vai tiesu iestādēm ir jārīkojas ātri vai taisnīgi kriminālprocesā. Atbildības pieaugums nav būtisks, jo šāda veida pasākumiem pirms tam ir jāizstrādā īpaša un atbalstìta tiesiskā valsts politika. Savukārt fakts ir tāds, ka lietu izskatīšana tiesā joprojām notiek ilgstoši. Bet būtu svarīgi noskaidrot, vai tas ir saistīts ar tiesu sistēmas neefektivitāti vai ar trūkumiem parlamenta izveidotajā tiesību sistēmā.

Atslēgvārdi: krimināltiesības, sods, profilakse. 
Jacek Zieliński. Changes in the Polish Policy of Application of Criminal Law after 2016

\section{References}

1. Andrejew, I. Kodeks karny. Krótki komentarz (Eng. The Penal Code. Short Commentary). Warszawa, 1988.

2. Andrejew, I. Sporne kwestie w kodeksie karnym (Eng. Disputed Issues in the Penal Code), Prokuratura i Prawo, 1970, No 7.

3. Buchała, K., Ćwiąkalski, Z., Szewczyk, M., Zoll, A. Komentarz do kodeksu karnego. Część ogólna (Eng. Commentary on the Penal Code. General Section). Warszawa, 1994.

4. Buchała, K., Zoll, A. Polskie prawo karne (Eng. Polish Criminal Law). Warszawa, 1997.

5. Cieślak, M. Zbieg szczególnego złagodzenia ze szczególnym obostrzeniem (Eng. The coincidence of a special relaxation with particular focus). Pal., 1977, No 5.

6. Glosa do uchwały SN z dnia 18 maja 1977 r., sygn. VII KZP 7/77 (Eng. Glose to the Supreme Court resolution of May 18, 1977, Ref. VII KZP 7/77). OSP, 1978, No 3.

7. Leśko, T. Glosa do wyroku SN z dnia 13 marca 1970 r., sygn. Rw 180/70 (Eng. Glose to the judgement of the Supreme Court dated March 13, 1970 Ref. RW 180/70). OSPiKA, 1971, No 9.

8. Stefańska, B. J., Zbieg podstaw nadzwyczajnego złagodzenia i obostrzenia kary (Eng. The coincidence of the baseline of extraordinary easing and tightening of punishment). Prokuratura i Prawo, 2017, No 2.

9. Ustawa - Kodeks Karny (Eng. Law - Criminal Code), 6/06/1997, Dz, U. 2016,1137.

10. Wolter, W. Nadzwyczajne złagodzenie kary przestępcom powrotnym (Eng. Extraordinary leniency of offenders). Prokuratura i Prawo, 1970, No 12.

11. Wyrok SN z dnia 11 czerwca 1990 r., sygn. V KRN 124/90 (Eng. Judgement of the Supreme Court of June 11, 1990, Ref. V KRN 124/90). OSNKW, 1991, No 1-3, poz. 5.

12. Wyrok SN z dnia 7 marca 1972 r., sygn. Rw 162/72 (Eng. Judgement of the Supreme Court of March 7, 1972, Ref. RW 162/72). OSNPG, 1972, No 7, poz. 104. 